\title{
Evolution and projection of knee arthroplasties from 2003 to 2030 in the state of São Paulo
}

\author{
Dogério Teixeira de Carvalho ${ }^{1}$ \\ (iD)Tiago Lobão Lopes ${ }^{1}$ \\ (iD) Marcelo Itiro Takano ${ }^{1}$ \\ (iD) Juliana Hoss Silva Lima' \\ (iD) Lucas Simões Arrebola ${ }^{1}$ \\ (D) Mauricio Lebre Colombo ${ }^{1}$ \\ (i) Fernando Gomes Tavares ${ }^{1}$
}

1. Serviço de Ortopedia e Traumatologia do Hospital do Servidor Público Estadual (HSPE) do Instituto de Assistência Médica ao Servidor Público Estadual de São Paulo (lamspe), São Paulo, SP, Brasil

http://dx.doi.org/10.1590/1806-9282.65.7.1001

\section{SUMMARY}

OBJECTIVE: Analyze data regarding total knee arthroplasty (TKA) carried out by the Public Health System (SUS) in the state of São Paulo from 2003 to 2010 and determine the projections expected for 2030.

METHODS: A cross-sectional study (observational). We analyzed 10,952 patients who underwent primary total knee arthroplasty (PTKA) and revision total knee arthroplasty (RTKA) in the state of São Paulo between 2003 and 2010. The collection of data based on ICD-10 and HAA (Hospital Admission Authorization) were provided by the Tabnet and Sigtap software (Management System for the Table of Procedures, Medications, and OPM by SUS). The following variables were analyzed: gender, number of PTKAs and RTKAs, and their projections. The information collected formed a database developed in Excel ${ }^{\circledR}$ for Windows, and the statistical analysis was performed by the Stata ${ }^{\circledR} 11$ SE and Minitab 16 software.

RESULTS: There was a significant difference in the prevalence of TKA between genders $(p<0.0001)$; most of the patients were females (7,891; 72\%). The projection for 2030 when compared with the first year of the series, 2003, indicates a growth of 428\% for PTKA and 1,380\% for RTKA, with a greater increase percentage of RTKA in males than in females (1,558\% and 1,318\%, respectively).

CONCLUSION: The proportions of the RTKA projection are much greater than those of PTKA by 2030, with a greater percentage of increase of RTKA in males than in females.

KEYWORDS: Osteoarthrosis. Arthroplasty. Knee. Forecasting.

\section{INTRODUCTION}

Over the past decades, there has been an increase in the longevity and life expectancy of the people in the state of São Paulo'. In 2000, the state's population was approximately 37 million inhabitants, of which $8.9 \%$ were elderly individuals (over 60 years)' In 2014 , this percentage increased to $11.89 \%$ of the more than 44 million inhabitants of São Paulo'. For 2030, it is expected that $21 \%$ of a total population of 48 million will be elderly individuals ${ }^{1}$. Recently, with the absolute number increase of the elderly population, the number of patients with osteoarthritis of the knee (OAK), particularly in the most populous Brazilian state ${ }^{2}$. Among the therapeutic options available for treating symptomatic advanced TKA, there is total knee arthroplasty (TKA) $)^{2}$. This surgery represents a technological breakthrough in OAK surgical procedures; it is effective to

DATE OF SUBMISSION: 09-Nov-2018

DATE OF ACCEPTANCE: 25-Nov-2018

CORRESPONDING AUTHOR: Rogério Teixeira de Carvalho

Rua Borges Lagoa, $1755-1^{\circ}$ andar - Sala 180 - CEP 04038-034, Vila Clementino, São Paulo/SP

Tel: (11) 4573-8271

E-mail: rtcarv27@gmail.com 
reduce pain, realign the affected lower limb, restore function, and optimize the decreased articular mobility $^{3}$. TKA allows a functional improvement in around $90 \%$ of the patients, with implants durability at around $95 \%$ in 15 years and $91 \%$ in 21 years ${ }^{2}$.

The development of instrumental support and particular devices, in addition to the improvement of surgical techniques and anesthetic procedures, broadened the indication criteria for KTA, including the age range over 40 years old, provided the procedure's eligibility conditions are met by younger and more active OAK patients ${ }^{4.5}$. The increase of TKA indications in the fifth and sixth decades of life has been reported in other countries, with emphasis on the public health system $^{6.7}$. The increased number of people in their 80's and 90's in clinical conditions to become TKA surgery candidates and the increased prevalence of obesity in the Brazilian population, which is a risk factor for OAK progression, has caused an increasing demand for TKA, and consequently of TKA revision cases (RTKA), thus determining a tendency of increased number of these surgeries in the coming years, especially in reference centers ${ }^{4,8,9}$. The greater number of indications for these types of arthroplasty will increase the health system's financial expenditures related to these primary interventions (ATKs) and surgical re-interventions in the coming decades ${ }^{2.4}$.

Thus, there was an expansion of the number of PTKAs and, consequently, an increase in revisions and the possibility of an even greater rise in numbers over the next 30 years ${ }^{10.11}$. Among the primary etiologies for RTKA, periprosthetic joint infection stands out, presenting an unfavorable impact on the functional clinical outcomes, increased hospital costs, and mortality rates in patients infected ${ }^{12,14}$. Other etiologies responsible for revisions are the loosening of the implants, instability, joint stiffness, and pain after the TKA ${ }^{12.15}$.

The objective of this study is to analyze data regarding total knee arthroplasty (TKA) carried out by the Public Health System (SUS) in the state of São Paulo from 2003 to 2010 and determine the projections expected for 2030.

\section{METHODS}

This study was conducted with the approval of the institution's ethics committee (CAAE: 48693115.1.0000.5463).

The data available were collected from the Tabnet software (a software developed to allow the technical staff of the Ministry of Health, State and Municipal Health Departments quickly tabulate files in DBF format - dbFast, which constitutes the basic components of the SUS Information Systems in their intranet or on their websites) and Sigtap system (Management System for the Table of Procedures, Medications, and OPM by SUS) concerning the epidemiological assessment of TKAs performed in the state of São Paulo, from 2003 to 2010. This time interval was selected due to the redefinition of the strategy for increased access to elective surgical procedures under the SUS in 2011 and regulated by Decree 1,340, of 29 June 2012, of the Ministry of Health, which encompassed knee arthroplasties. These programs are administered by the Hospital Information System of SUS - SIH/SUS, managed by the Ministry of Health, through the Department of Health Assistance, along with State and Municipal Health Departments, and processed by the Datasus Department of Informatics of SUS, of the Executive Secretariat of the Ministry of Health. The instruments used to record the patients included in the program were the HAAs (Hospital Admission Authorization) of patients admitted with the underlying disease, according to the International Classification of Diseases (ICD - 10). The ICDs selected were M17 for knee arthrosis and T84 for complications of prosthetic devices.

The hypothesis is that the demand for PTKA and RTKA will increase substantially by the year 2030 . To test this hypothesis, we performed statistical projections, by means of linear regression, of the total number of PTKAs and RTKAs between 2011 and 2030 based on the medical records available in the database of the Unified Health System (SUS) for the state of São Paulo, between January 2003 and December 2010.

We analyzed data concerning TKAs (primary and revision) performed by SUS in the state of São Paulo, between January 2003 and December 2010, to determine the expected trends and projections of these arthroplasties by 2030 . The variables evaluated in this study were the type of arthroplasty, the date of surgery and gender, which were presented in tables with absolute and relative frequency distribution. The normality of the variables was tested using the Shapiro Wilk test ${ }^{10}$, and the proportion comparison of the variables was performed using the Test for the Equality of Two Proportions ${ }^{16}$. The trend analysis was performed by polynomial regression models. All analyses were performed with a significance level of $5 \%$; therefore, results were considered statistically significant when p-value $<0.05$, always considering two-tailed alternative hypotheses. 
The information collected formed a database developed in Excel ${ }^{\circledR}$ for Windows, and the statistical analysis was performed by the Stata ${ }^{\circledR} 11 \mathrm{SE}$ and Minitab 16 software.

\section{RESULTS}

This study analyzed 10,952 patients who underwent TKA between January 2003 and December 2010. There was a significant difference in prevalence between genders $(p<0.0001)$, with mostly female patients $(7,891 ; 72 \%)$, i.e., there were, on average, 2.6 times more procedures of TKA performed in women than in men (Table 1).

There was a significant increase in PTKA and RTKA surgeries $(p<0.0001)$ in the period analyzed. In 2003, the first year analyzed, 830 TKAs and RTKAs 91 were performed. In the last year analyzed, 2010, 1,839 TKAs and 420 RTKAs were performed, an increase of $122 \%$ and $362 \%$, respectively, in the number of surgeries performed between the first and the last year analyzed (Table 2).

As for the projections, the results showed that by 2030 , the number of TKAs would increase with statistical significance $(p<0.0001)$. When compared with the first year of the series, 2003, the projection indicates a growth of $428 \%$ for PTKAs and $1,380 \%$ for

TABLE 1. DISTRIBUTION OF TKAs PER GENDER, FROM 2003 TO 2010.

\begin{tabular}{l|l|l|l} 
Gender & No. & $\%$ & p \\
\hline Fem & 7,891 & $72 \%$ & $<0.0001$ \\
\hline Male & 3,061 & $28 \%$ & \\
\hline Total & 10,952 & $100 \%$ & \\
\hline
\end{tabular}

RTKAs (Table 3 and Figure 1). It should be noted that the proportion ratio between the types of surgery is decreasing: in 2003, the proportion ratio between PTKA and RTKA was 9.1:1, i.e., nine primary surgeries were performed, on average, for each revision surgery. In the projection for 2030, the proportion dropped to 3.3:1, i.e., it indicates that for every three primary surgeries, one revision surgery will be performed.

The result showed that, for 2030, the number of PTKAs increased with statistical significance $(p<0.0001)$ for the female gender. When compared with the first year of the series, 2003, the projection indicates a growth of $388 \%$ for PTKAs and $1,318 \%$ for RTKAs, with a 3.2:1 ratio for the projections.

The results showed that, for 2030, the number of TKA increased with statistical significance $(p<0.0001)$ for males. When compared with the first year of the series, 2003, the projection indicates a growth of $552 \%$ for PTKAs and 1,558\% for RTKAs, with a 3.3:1 ratio for the projections (Figure 2).

\section{DISCUSSION}

The most important finding of this study was that the TKA demand, for both primary and revision, has a growing trend, with a projected increase of $428 \%$ for the primary type and $1,380 \%$ for revisions, by 2030 . Although primary prosthesis are more frequent, the ratio between the proportion of primary prostheses and revisions is decreasing considerably (9.1:1 in 2003 and 3.3:1 in 2030).

Our study showed an increasing trend of TKA, which was also found in studies conducted in other countries. In the United States, a study carried out over a similar period of time found that the demand

TABLE 2. DISTRIBUTION OF TKAs PER GENDER, FROM 2003 TO 2010.

\begin{tabular}{|c|c|c|c|c|c|c|c|c|c|}
\hline \multirow[t]{2}{*}{ Type of ATK } & \multicolumn{8}{|c|}{ Year } & \multirow{2}{*}{$\begin{array}{l}\text { Growth \% (initial } \\
\text { year x final year) }\end{array}$} \\
\hline & 2003 & 2004 & 2005 & 2006 & 2007 & 2008 & 2009 & 2010 & \\
\hline Primary & 830 & 840 & 917 & 1001 & 1105 & 1187 & 1552 & 1839 & $122 \%$ \\
\hline Revision & 91 & 102 & 116 & 133 & 169 & 333 & 317 & 420 & $362 \%$ \\
\hline Total & 921 & 942 & 1033 & 1134 & 1274 & 1520 & 1869 & 2259 & $145 \%$ \\
\hline
\end{tabular}

TABLE 3. ATKS EVOLUTION FROM 2003 TO 2010, AND PROJECTIONS BY 2030.

\begin{tabular}{|c|c|c|c|c|c|c|c|c|c|c|c|c|c|}
\hline \multirow{2}{*}{$\begin{array}{l}\text { Type of } \\
\text { ATK }\end{array}$} & \multicolumn{8}{|c|}{ Historical series } & \multicolumn{4}{|c|}{ Projections } & \multirow{2}{*}{$\begin{array}{l}\text { Growth \% } \\
\text { (initial x final) }\end{array}$} \\
\hline & 2003 & 2004 & 2005 & 2006 & 2007 & 2008 & 2009 & 2010 & 2015 & 2020 & 2025 & 2030 & \\
\hline Primary & 830 & 840 & 917 & 1001 & 1105 & 1187 & 1152 & 1839 & 2326 & 3013 & 3700 & 4386 & $428 \%$ \\
\hline Revision & 91 & 102 & 116 & 133 & 169 & 333 & 317 & 420 & 621 & 863 & 1105 & 1347 & $1380 \%$ \\
\hline $\begin{array}{l}\text { Primary } \\
\text { ratio }\end{array}$ & $9.1: 1$ & $8.2: 1$ & $7.9: 1$ & $7.5: 1$ & $6.5: 1$ & $3.6: 1$ & $4.9: 1$ & $4.4: 1$ & $3.7: 1$ & $3.5: 1$ & $3.3: 1$ & $3.3: 1$ & - \\
\hline
\end{tabular}


for PTKA and RTKA is expected to grow $673 \%$ and $601 \%$, respectively, between 2005 and $2030^{11.17}$. Data analyses relating to England and Wales suggest that, by 2030, the volume of TKAs and RTKAs will have increased by $117 \%$ and $332 \%$, respectively, between
2012 and $2030^{18}$. Another European study presented data that predict a $297 \%$ demographic projection for the number of TKAs by 2030 in the Netherlands ${ }^{19}$. Another study showed that TKAs would increase by $45 \%$ over the next three decades in Italy ${ }^{20}$.

FIGURE 1. ATKS EVOLUTION FROM 2003 TO 2010 AND PROJECTIONS BY 2030.

Projeçãodas Cirurgias de ATJ até 2030

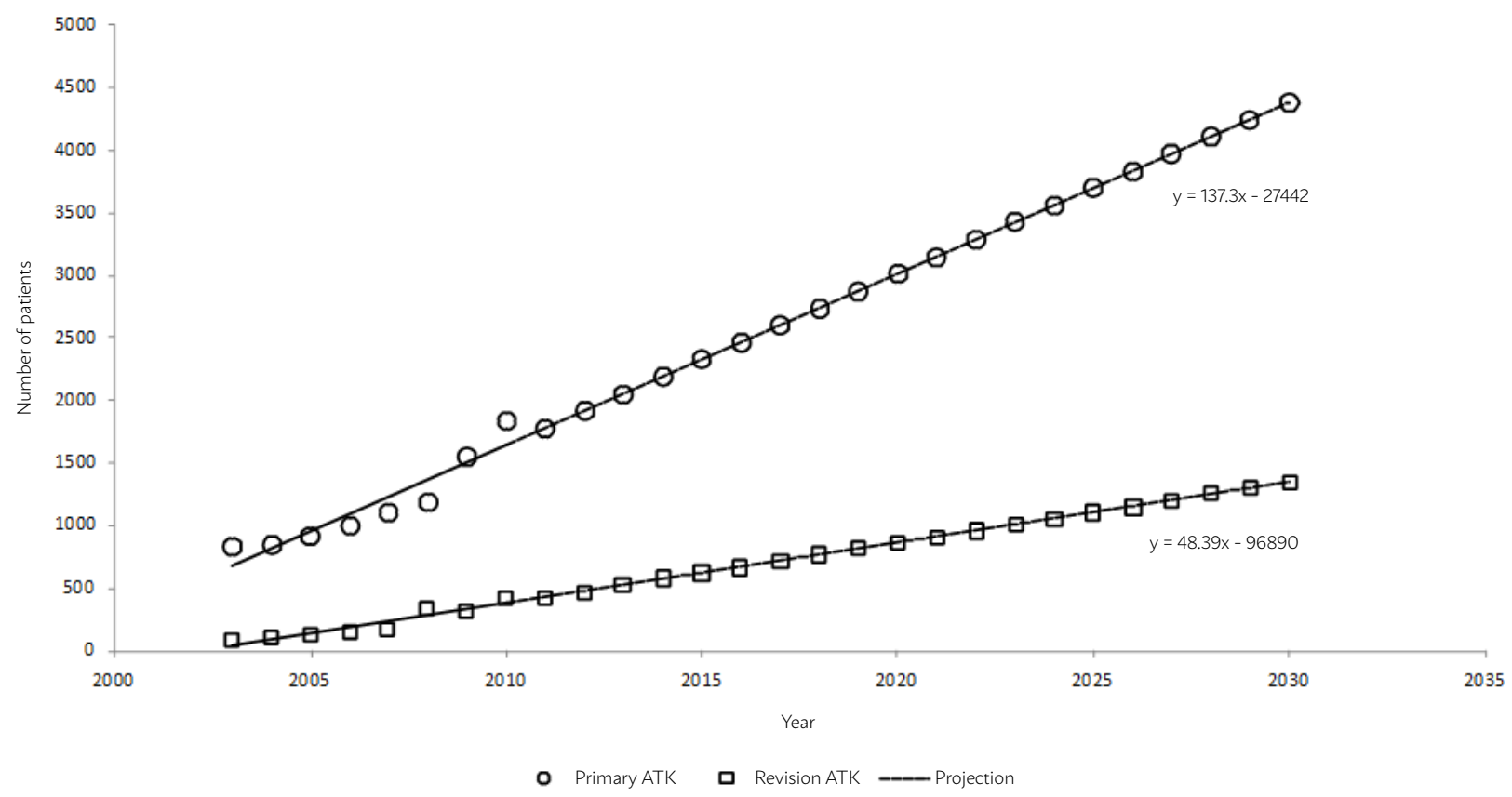

FIGURE 2. RATKS EVOLUTION FROM 2003 TO 2010 AND PROJECTIONS BY 2030, PER GENDER

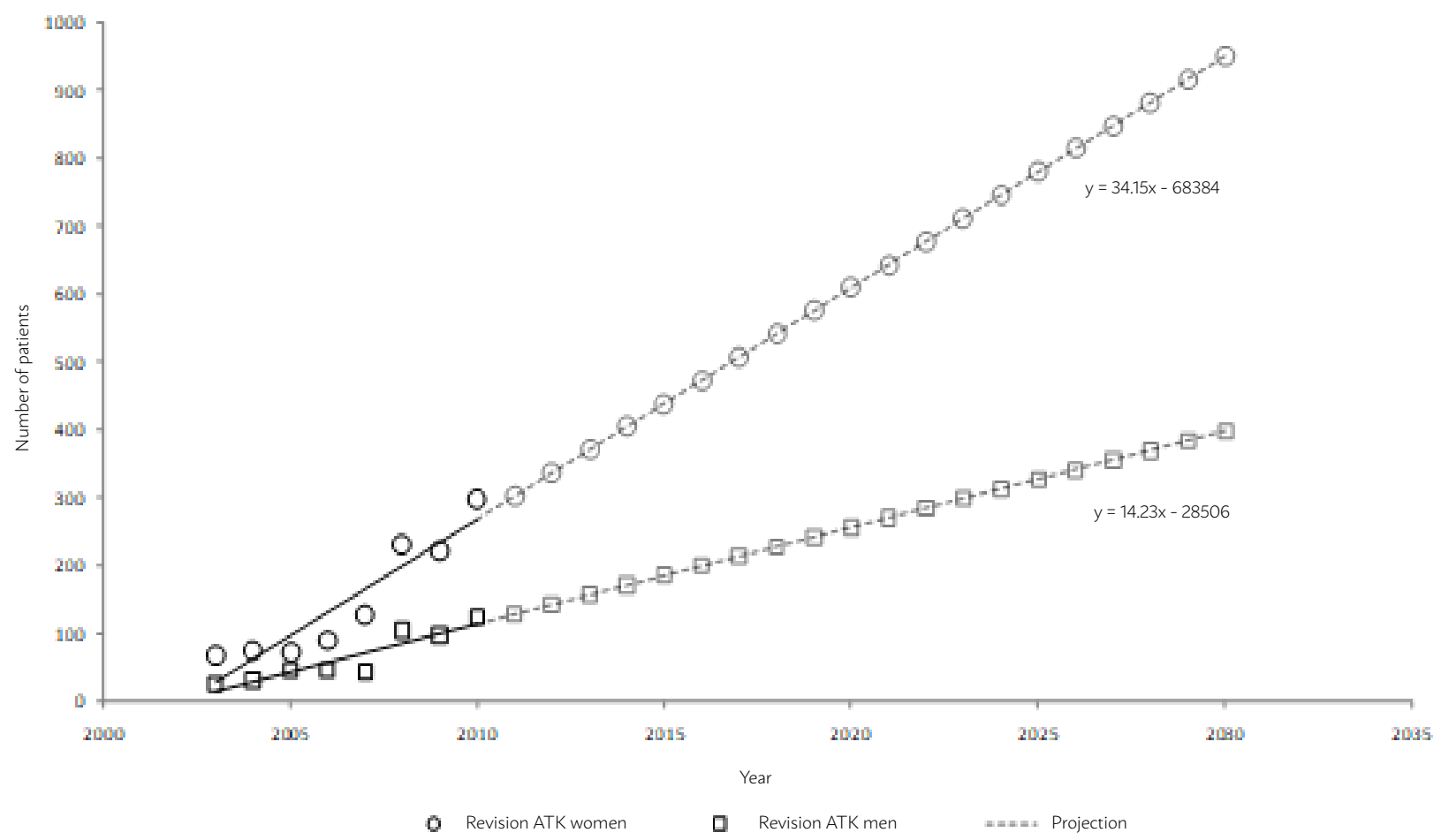


Another study reports that event young patients (under 65 years) will have an increase in the number of prosthesis and revisions by 2030, and highlights the weight that young patients may represent in the future of the demand for primary and revision surgery ${ }^{21}$. A study conducted in the United States and in Ontario, Canada, demonstrated that the rates of TKA have increased in North America, with the contribution of the increased number of young people undergoing prosthetic replacement of joints, which indicated an expansion of indications ${ }^{22}$. Another international study corroborates the increased projection, estimating a $183 \%$ growth of TKAs by $2026^{23}$. This increase in the demand for TKAs and RTKAs will create a significant socioeconomic burden and require planned and programmed health strategies to ensure the necessary resources are allocated to meet the demand of the population affected by OAK ${ }^{17.23}$.

In the gender analysis, when confronted with other international case series, we found an increase proportionally similar for men and women ${ }^{23}$. However, after analyzing the procedures based on type and gender, we saw a greater percentage increase in RTKA in males than in females $(1,558 \%$ and $1,318 \%$, respectively). This disparity justifies further research to determine the extent to which it reflects changes in the risk of the disease or inequalities in public health services. Women usually seek early medical care due to functional disabilities associated mainly to complaints of pain during walking and daily living activities, while men postpone medical assistance and complain about the deleterious effects of OAK on leisure activities ${ }^{24}$. Women have a longer life expectancy and have presented increased use of TKA in recent years, but face greater barriers to access to the surgical treatment ${ }^{2,5,25}$. Women are willing to undergo surgery, just like men, but are less likely to receive an indication to a specialist in comparison with men with advanced $\mathrm{OAK}^{25}$.

Additional national epidemiological data, such as the latest updated projections of this study, provide a forecast for surgeons, hospitals, health services and the formulators of public policies to plan for the future demand for ATKs and RTKAs over the next decades ${ }^{2.26}$. The data relating to projections made in this study identified a proportional increase of RTKA indications in comparison with to TKA over the next decade, allowing for a planned health budget and the development of strategic measures to encompass this increased demand for knee arthroplasty surgeries.
Among the possible etiologies responsible for the increased number of RTKAs in the sample analyzed, periprosthetic joint infection (PJI) stands out in several different stages, i.e., early (less than three months), intermediate (between 3 and 24 months) and late (after 24 months), according to the classification proposed by Zimmerli et al. ${ }^{27}$. The lack of standardization and multi-professional teams specialized in the diagnosis and treatment of PJI made the follow-up of these patients in SUS even more difficult. Two national studies conducted in public hospitals in São Paulo, which included part of the period of time analyzed in our study, corroborated this possibility ${ }^{28.29}$. Since then, protocols have been implemented and developed jointly by infectologists, anesthesiologists, and nursing professionals to prevent, diagnose, monitor, and optimize therapeutic strategies to minimize such complication $^{30}$.

The increase of prosthetic knee joint replacement surgeries is an urgent reality and requires improvements in the management of hospitals, training of medical professionals, and specialized nursing teams, due to the positive association between the experience of the surgeon and the surgical volume of knee arthroplasties performed at referral centers with more favorable outcomes, lower rate of complications, and lower costs ${ }^{2,9,11,14}$. The projections in this study are limited to an extrapolation of historical data. The trends established may not persist in the future because of the influence of certain factors, such as improvements in the implant technology or new pharmaceutical discoveries that may impact the physiopathology and progression of OAK.

The weaknesses of this study are the lack of standardization of surgical techniques, the absence of data such as patient age and comorbidities, which could identify risk factors for arthroplasties, absence of etiologies and indications for the surgery, complications related to the procedure and the lack of knowledge of materials and implants used for the knee prostheses. These data were not collected due to the diversity of information from medical records and absence of interviews with the patients who underwent surgery.

\section{CONCLUSION}

The projected proportions of revision prosthesis are much greater than those of primary prosthesis by 2030. The increasing percentage of RTKAs was greater in males when compared with females. 


\section{RESUMO}

OBJETIVO: Analisar os dados referentes às artroplastias totais de joelho (ATJ) realizadas pelo Sistema Público de Saúde (SUS) no estado de São Paulo de 2003 a 2010 e determinar as projeções esperadas para 2030.

MÉTODOS: Estudo transversal (observacional). Foram analisados 10.952 pacientes que realizaram artroplastia total de joelho primária (ATJP) e revisão (ATJR) no estado de São Paulo entre 2003 e 2010. A coleta de dados baseados no CID-10 e AlH (Autorização de Internação Hospitalar) foram fornecidos pelo programa Tabnet e Sigtap (Sistema de Gerenciamento da Tabela de Procedimentos, Medicamentos e OPM do SUS). Foram analisadas as seguintes variáveis: gênero, número de ATJP e número de ATJR, além de suas projeções. As informações coletadas formaram um banco de dados desenvolvido no programa Excel ${ }^{\circledR}$ for Windows e a análise estatística foi realizada pelos softwares Stata ${ }^{\circledR} 11$ SE e Minitab 16.

RESULTADOS: Houve diferença significativa na prevalência da AT) entre os gêneros ( $p<0,0001)$, sendo a maioria do gênero feminino (7.891; 72\%). A projeção para 2030 quando comparado com o primeiro ano da série, 2003, indica um crescimento de 428\% para as ATJP e $1.380 \%$ nas ATJR, com uma porcentagem de aumento maior nas ATJR no gênero masculino do que no feminino (1.558\% e 1.318\%, respectivamente).

CONCLUSÃO: As proporções de projeção da ATJR se mostram muito maiores do que nas ATJP até o ano de 2030, percebendo-se uma porcentagem de aumento maior de ATJR no gênero masculino comparado ao feminino.

PALAVRAS-CHAVE: Osteoartrose. Artroplastia. Joelho. Previsões.

\section{REFERENCES}

1. Brasil. Ministério da Saúde. Departamento de Informática do SUS (DATASUS). Banco de dados do DATASUS. 2012. [cited 2 set 2014] Available from: http://tabnet.datasus.gov.br/cgi/tabcgi.exe?ibge/cnv/popSP.def.

2. Carvalho RT, Canté JC, Lima JH, Tavares LA, Takano MI, Tavares FG. Prevalence of knee arthroplasty in the state of São Paulo between 2003 and 2010. Sao Paulo Med J. 2016;134(5):417-22.

3. Ethgen $O$, Bruyère $O$, Richy F, Dardennes $C$, Regisnter JY. Health-related quality of life in total hip and total knee arthroplasty. A qualitative and systematic review of the literature. J Bone Joint Surg Am. 2004;86(5):963-74.

4. March LM, Bagga H. Epidemiology of osteoarthritis in Australia. Med J Aust. 2004;180(5 Suppl):S6-10.

5. Ibrahim T, Bloch B, Esler CN, Abrams KR, Harper WM. Temporal trends in primary total hip and knee arthroplasty surgery: results from a UK regional joint register, 1991-2004. Ann R Coll Surg Engl. 2010;92(3):231-5.

6. Leskinen J, Eskelinen A, Huhtala H, Paavolainen P, Remes V. The incidence of knee arthroplasty for primary osteoarthritis grows rapidly among baby boomers: a population-based study in Finland. Arthritis Rheum. 2012;64(2):423-8.

7. Nemes S, Rolfson O, W-Dahl A, Garellick G, Sundberg M, Kärrholm ). Historical view and future demand for knee arthroplasty in Sweden. Acta Orthop. 2015;86(4):426-31.

8. Coggon D, Reading I, Croft P, McLaren M, Barrett B, Cooper C. Knee osteoarthritis and obesity. Int J Obes Relat Metab Disord. 2001;25(5):622-7.

9. Lee R, Kean W. Obesity and knee osteoarthritis. Inflammopharmacology. 2012;20(2):53-8.

10. Kurtz S, Mowat F, Ong K, Chan N, Lau E, Halpern M. Prevalence of primary and revision total hip and knee arthroplasty in the United States from 1990 through 2002. J Bone Joint Surg Am. 2005;87(7):1487-97.

11. Kurtz S, Ong K, Lau E, Mowat F, Halpern M. Projections of primary and revision hip and knee arthroplasty in the United States from 2005 to 2030. J Bone Joint Surg Am. 2007;89(4):780-5.

12. Koh CK, Zeng I, Ravi S, Zhu M, Vince KG, Young SW. Periprosthetic joint infection is the main cause of failure for modern knee arthroplasty: an analysis of 11,134 knees. Clin Orthop Relat Res. 2017;475(9):2194-201.

13. Kurtz SM, Lau E, Watson H, Schmier JK, Parvizi J. Economic burden of periprosthetic joint infection in the United States. J Arthroplasty. 2012;27(8 Suppl):61-5.e1.

14. Boddapati V, Fu MC, Mayman DJ, Su EP, Sculco PK, McLawhorn AS. Revision total knee arthroplasty for periprosthetic joint infection is associated with increased postoperative morbidity and mortality relative to noninfectious revisions. J Arthroplasty. 2018;33(2):521-6.

15. Khan M, Osman K, Green G, Haddad FS. The epidemiology of failure in total knee arthroplasty: avoiding your next revision. Bone Joint J. 2016;98B(1 Suppl A):105-12
16. Vieira S. Bioestatística: tópicos avançados. $2^{a}$ ed. São Paulo: Campus; 2004. p.212.

17. Kurtz SM, Ong KL, Schmier J, Mowat F, Saleh K, Dybvik V, et al. Future clinical and economic impact of revision total hip and knee arthroplasty. I Bone Joint Surg Am. 2007;89(Suppl 3):144-51.

18. Patel A, Pavlou G, Mújica-Mota RE, Toms AD. The epidemiology of revision total knee and hip arthroplasty in England and Wales: a comparative analysis with projections for the United States. A study using the National Joint Registry dataset. Bone Joint |. 2015;97-B(8):1076-81.

19. Otten R, van Roermund PM, Picavet HS. Trends in the number of knee and hip arthroplasties: considerably more knee and hip prostheses due to osteoarthritis in 2030. Ned Tijdschr Geneeskd. 2010;154:A1534.

20. Romanini E, Decarolis F, Luzi I, Zanoli G, Venosa M, Laricchiuta P, et al. Total knee arthroplasty in Italy: reflections from the last fifteen years and projections for the next thirty. Int Orthop. 2019;43(1):133-8.

21. Kurtz S, Lau E, Ong K, Zhao K, Kelly M, Bozic KJ. Future young patient demand for primary and revision joint replacement: national projections from 2010 to 2030. Clin Orthop Relat Res. 2009;467(10):2606-12.

22. Ravi B, Croxford R, Reichmann WM, Losina E, Katz JN, Hawker GA. The changing demographics of total joint arthroplasty recipients in the United States and Ontario from 2001 to 2007. Best Pract Res Clin Rheumatol. 2012;26(5):637-47.

23. Hooper G, Lee Al, Rothwell A, Frampton C. Current trends and projections in the utilisation rates of hip and knee replacement in New Zealand from 2001 to 2026. N Z Med J. 2014;127(1401):82-93.

24. Toye FM, Barlow J, Wright C, Lamb SE. Personal meanings in the construction of need for total knee replacement surgery. Soc Sci Med. 2006;63(1):43-53

25. Mota RE, Tarricone R, Ciani O, Bridges JF, Drummond M. Determinants of demand for total hip and knee arthroplasty: a systematic literature review. BMC Health Serv Res. 2012;12:225.

26. Kurtz SM, Ong KL, Lau E, Bozic KJ. Impact of the economic downturn on total joint replacement demand in the United States: updated projections to 2021. J Bone Joint Surg Am. 2014;96(8):624-30.

27. Zimmerli W, Trampuz A, Ochsner PE. Prosthetic-joint infections. N Engl J Med. 2004;351(16):1645-54.

28. D'Elia CO, Santos ALG, Leonhardt MC, Lima ALLM, Pécora JR, Camanho GL. Tratamento das infecções pós artroplastia total de joelho: resultados com 2 anos de seguimento. Acta Ortop Bras. 2007;15(3):158-62.

29. Cury RPL, Cinagawa EHT, Camargo OPA, Honda EK, Klautau GB, Salles MJC. Tratamento de infecção após artroplastia total de joelho. Acta Ortop Bras. 2015;23(5):239-43

30. Carvalho Júnior LH, Temponi EF, Badet R. Infecção em artroplastia total de joelho: diagnóstico e tratamento. Rev Bras Ortop. 2013;48(5):389-96. 